\title{
К вопросу о признаках подражаний поздним боспорским статерам
}

\author{
М.М. Чореф \\ Нижегородский государственный университет им. Н.И. Лобачевского, \\ Россия, 603950, г. Нижний Новгород, ул. Гагарина, 23 \\ E-mail: choref@yandex.ru
}

\begin{abstract}
Аннотация. Наша цель - разработка методики выявления подражаний боспорским монетам позднейшего чекана. Проблема в том, что выпущенные тогда статеры были оформлены столь безыскусно, что подчас их крайне трудно отличить от реплик, отчеканенных непрофессиональными мастерами, лишь волей случая обратившихся к ремеслу фальшивомонетчика. Изображения царей и императоров на них примитивны и гротескны, а надписи подчас изобилуют ошибками. Полагаем, что есть только два критерия, пригодные для выделения позднейших официальных серий: массовость выпуска, для которой характерно использование множества связанных штемпелей, причем с применением не только вновь изготовленных, но и предыдущих лет эмиссии, а также использование эталонов для формовки чеканов. Идет речь о технологиях, применяемых тогда на государственных монетных дворах. Заметим, что фальшивомонетчикам для работы было достаточно лишь пары штемпелей, которые использовать до полного разрушения. Обосновываем этот тезис на примере небольшой группы статеров 631 г. б. э. Полагаем, что эти крайне небрежно оформленные монеты были отчеканены на государственных денежных дворах.
\end{abstract}

Ключевые слова: нумизматика, экономика, Боспор, статер, дифференты.

Для цитирования: Чореф М.М. 2020. К вопросу о признаках подражаний поздним боспорским статерам. Via in tempore. История. Политология, 47 (4): 693-703. DOI: 10.18413/2687-0967-202047-4-693-703.

\section{On the issue of signs of imitations of the late Bosporus staters}

\author{
Michael M. Choref \\ Lobachevsky State University of Nizhni Novgorod, \\ 23 Gagarin Avenue, Nizhnij Novgorod, 603950, Russia \\ E-mail: choref@yandex.ru
}

\begin{abstract}
Our goal is to develop a methodology for identifying imitations of the late coins of Bosporus coinage. The problem is that the staters released at that time were so naive that it is sometimes extremely difficult to distinguish them from replicas minted by unprofessional craftsmen who, by chance, turned to the counterfeiter's craft. Images of kings and emperors on them are primitive and grotesque, and the inscriptions are often replete with errors. We believe that there are only two criteria suitable for highlighting the latest official series: mass release, which is characterized by the use of many related stamps, using not only newly manufactured, but also previous years of issue, as well as the use of models for the production of stamps. We are talking about technologies used then at state mints. Note that counterfeiters needed only a couple of stamps to work, which they must use until they are completely destroyed. We substantiate this thesis on the example of a small group of staters of $631 \mathrm{BE}$. We believe that these extremely carelessly issued coins were minted at state mint.
\end{abstract}

Keywords: numismatics, economics, Bosporus, stater, differents. 
For citation: Choref M.M. On the issue of signs of imitations of the late Bosporus staters. Via in tempore. History and political science, 47 (4): 693-703 (in Russian). DOI: 10.18413/2687-0967-2020-474-693-703.

Сравнительно недавно в соавторстве с крымским исследователем Д.В. Андриевским [Андриевский, Чореф, 2015, с. 91-94], мы подготовили предварительное сообщение о весьма интересной монете (рис. 1,1 ):

Л. с.: ВАСІ $А Е \Omega$ РНСКОҮПОРІС. Бюст мужчины в диадеме, развернутый вправо. Пряди его длинных волос переданы как параллельные кривые линии. Правее подбородка и шеи размещен дифферент 4.

O. с.: AVX. Первая буква с косой соединяющей линией. Также на оборотной стороне монеты оттиснуто развернутое вправо изображение мужчины с короткими волосами, в лавровом венке с длинными лентами. Композиция обрамлена окружностью из крупных редких точек.

Монета отчеканена из бронзы. Ее диаметр - 2,0 см, а вес - 4,35 г.

Как видим, монета была отчеканена от имени «царя Рескупорида». Этому выводу не противоречит оформление реверса. На нем отчеканено изображение римского императора, выполненное в стиле, характерном для поздних монет Боспора. Что же касается легенды «AVX», то в ней есть все основания видеть обозначение даты выпуска по б. э.

И сразу же заметим, что оно весьма неординарное. Да, в «А» и в «Х» есть все основания видеть символьные обозначения чисел - 1 и 500 соответственно. Однако «V» вред ли может быть истолкован как «v» -50 или «v»» - 400. Дело в том, что на античных, в т. ч. и на боспорских монетах легенды, как правило, составляли исключительно из прописных

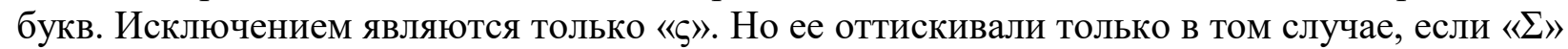
была последней буквой в обозначении даты. Так что вместо «v» должны были отчеканить «N» [Анохин, 2011; Фролова, 1997a; Фролова, 1997b]. Приходим к выводу, что изучаемая монета не могла быть отчеканена в 651 г. б. э. ${ }^{12}$ (354/355 г. н.э.).

Далее, символ «Х», входящий в состав «AVX», явно использовался для обозначения числа 500. Следовательно, у нас нет оснований полагать, что это буквосочетание включает прописную «V». Учитывая это обстоятельство, мы в свое время допустили, что этот символ является вертикально отраженной «А» [Андриевский, Чореф, 2015, с. 91]. Если это так, то из «AVX» получаем «А $\Lambda \mathrm{X}$ », которое, в свою очередь, могло быть использовано для обозначения вполне допустимой даты - 631 г. б. э. (334/335 г. н. э.). Чему, повторимся, не противоречит оформление монеты. Определенно, она была выпущена на Боспоpe, причем при ее последних государях. Полагаем, что изучаемую монету следует отнести к эмиссии последнего боспорского государя Рескупорида V (318/319-342/343).

Однако мы пока не считаем вопрос о датировании монеты исчерпанным. Дело в том, что администраторы сайта «Монеты Боспора», на базе которого создан наиболее полный каталог монет одноименного государства, за что мы их сердечно благодарим, заключили ${ }^{13}$, что в «AVX» следует видеть «AKX». Мы эту точку зрения принять не можем. Дело в том, что символ «К» на боспорских монетах как этого года выпуска [Анохин, 2011, № 2171], так и более позднего чекана, прописывали куда отчетливее, так, чтобы все его элементы были различимы [Анохин, 2011, № 2168-2202; Фролова, 1997b, с. 337-371,

12 Что, к слову, укладывается в концепцию датирования правления Рескупорида V, обоснованную Н.А. Фроловой, М.Г. Абрамзоном и их соавторами [Абрамзон, 2011; Абрамзон, Новичихин, Сапрыкина, Смекалова 2019; Абрамзон, Фролова, 2007-2008; Абрамзон, Фролова, Горлов, 2002; Фролова, 1997b, c. 131-138].

${ }^{13}$ Монета: 770-5138. URL: https://bosporan-kingdom.com/770-5138/ (дата обращения: 04.07.2020). 
табл. XCIV, 24-30, XCV-CXI, CXII, 1-4]. В любом случае он всегда составлялся из двух наклонных, соприкасающихся в одной точке линий, и проходящей через нее вертикальной. Причем этот символ никогда не разворачивали на $90^{\circ}$ по часовой стрелке так, чтобы его наклонные элементы напоминали «V» [Анохин, 2011, № 2168-2202; Фролова, 1997b, c. 337-371, табл. XCIV, 24-30, XCV-CXI, CXII, 1-4]. К слову, стандартно оформленная «К» размещена на аверсе изучаемой монеты (рис. 1,1$)$. Так что на ее реверсе оттиснута именно «V». Причем концы гаст этой буквы, как будто бы древний резчик поставил перед собой цель снять вопрос ее атрибуции, обозначены точками (рис. 1,1$)$.

Чем же еще интересна эта монета? Дело в том, что боспорские статеры 631 г. б. э. не были известны ни В.А. Анохину [Анохин, 2011], ни Н.А. Фроловой [Фролова, 1997b, с. 136, 371]. Правда, одну из таких монет изучил Д. Сестини. Но, к сожалению, ученый ограничился ее описанием и не привел даже рисунка [Sestini, 1831, p. 79, No. 21]. Судя по его краткому описанию, на лицевой стороне монеты выбито изображение боспорского царя, окружен-

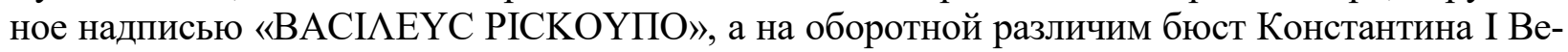

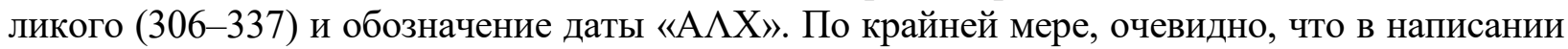
даты на монете, известной Д. Сестини, не было ошибки. И, что крайне важно, ученый не выявил на ней дифференты [Sestini, 1831, p. 79, No. 21]. Так что у нас есть все основания заключить, что в 631 г. б. э. статеры чеканили по крайней мере в двух эмиссионных центрах, использующих две пары штемпелей ${ }^{14}$ [Чореф, 2012b, с. 171-200; Чореф, 2014b, с. 456-487; Чореф, 2015, с. 279-299]. Первый, судя по отсутствию эмиссионных символов, работал в столице [Чореф, 2011, с. 254; Чореф, 2012a, с. 47-51; Чореф, 2012b, с. 177; Чореф, 2014a, с. 333]. Не удивительно, что на этой монете размещено верное обозначение даты. Второй же, использовавший дифферент Ч, как мы полагаем, располагался на восточном берегу Боспорского пролива - в важнейшей резиденции боспорских государей со времен Рескупорида IV (242/243-253/254, 254/255-257/258, 261/262-267/268, 275/276-276/277 гг. н. э.) ${ }^{15}$ [Чореф, 2012b, с. 187-195]. Но, как видим, в 631 г. б. э. этот эмиссионный центр не

${ }^{14}$ Вряд ли есть основания полагать, чтобы в одном и том же центре в один и тот же год в рамках одной эмиссии чеканили монеты с правильно размещенной и перевернутой цифрой в обозначении даты выпуска. Этот факт как нельзя лучше свидетельствует в пользу нашей трактовки дифферентов на боспорских монетах как эмиссионных символов - меток денежных дворов.

${ }^{15}$ К сожалению, наша точка зрения была поставлена под сомнение крымским историком В.В. Панченко. Он, как нельзя хуже зарекомендовав себя в качестве исследователя биографии Одената речь идет о статье «Морской поход племен Северного Причерноморья 266 г. н. э. на Гераклею и ситуация на Боспоре» [Панченко, 2017, с. 52-62], на которую мы своевременно дали отзыв [Чореф, 2017, с. 46-55], счел возможным внести свой вклад и в изучение дифферентов на боспорских монетах [Панченко, 2020, с. 86108]. Исследователь пришел к выводу, что Ж «первоначально ... являлся одним из символов правителей царства, причем вне зависимости от их происхождения» [Панченко, 2020, с. 98]. При этом он полагает, что Гигиэнонт (3-я четв. II в. до н. э.) не являлся Спартокидом [Молев, 2017, с. 79-80, 83]. Позже, в римский период, по мнению В.В. Панченко, этот знак «являлся символом правящей династии Тибериев Юлиев, а не правителей Боспора вообще». К первым он не относит Ининфимея (233/234-238/239), Фарсанза (253/254254/255), Тейрана (266/267, 275/276-278/279) и Радамсадия (309/310-322/323) [Панченко, 2020, с. 98]. Однако, судя по официальным надписям, первый и третий государи были Тибериями Юлиями (КБН 36 , $1249,1250)$. В то же время неупомянутый исследователем Рескупорид V в текстах надписей (КБН 65, 66, $1112)$ не представлен как Тиберий Юлий. Это, однако, не дает нам оснований считать его узурпатором. Вполне возможно, что и его соправитель Радамсадий (КБН 66) также был представителем законной династии. Далее, знакам ираноязычных народов Северного Причерноморья и Таврики, в т. ч. и тем, которые использовали боспорские государи из династии Тибериев Юлиев, посвящена обширная литература. Отметим только классические труды Э.И. Соломоник [Соломоник, 1959] и С.А. Яценко [Яценко, 2001]. Важно то, что ученые не отнесли «трезубцы», аналогичные размещенным на боспорских монетах, к группе царских знаков. Напомним, что на упомянутых В.В. Панченко тамгах этих государей зубцы направлены не вверх, а вниз. Приходим к выводу, что трактовка этого дифферента, а, судя по характеру использования, он таковым и являлся, предложенная В.В. Панченко, столь же алогична и нелепа, как и его рассуждения в статье «Морской поход племен Северного Причерноморья 266 г. н. э. на Гераклею и ситуация на Боспоре» [Панченко, 2017, с. 52-62]. О крайне слабом уровне подготовки В.В. Панченко говорит и наличие в Summary его труда грубейших ошибок. Так, он привел вместо «Pharsanzes», «Ininthimeus», «Teiranes» и 
был должным образом укомплектован высокопрофессиональными кадрами. Вследствие этого на его монетах вместо «А $\Lambda \mathrm{X}$ » разместили «AVX».

Однако мы отдаем себе отчет в том, что наш вывод может быть поставлен под сомнение. Ведь, как уже было сказано выше, изображения на монете исполнены крайне примитивно, можно даже сказать - гротескно, а легенда аверса содержит ошибки. Так что есть определенные основания считать ее репликой. В таком случае предлагаемая датировка только по обозначению даты не выглядит убедительной. И вполне возможно, что изучаемая монета могла быть выпущена значительно позже, после прекращения эмиссии боспорских статеров ${ }^{16}$. Но мы с таким выводом не согласны. Попытаемся обосновать нашу точку зрения.

Ранее нами было подмечено [Андриевский, Чореф, 2015, с. 91], что написание «РНСКОҮПОРІС» наряду с широко распространенным «РІСКОҮПОРІС» вполне допустимо для монет Рескупорида V. Основываемся на выводах Н.А. Фроловой [Фролова, $1997 b$, с. 323-372]. Остается лишь констатировать, что резчик штемпеля аверса не допустил ошибку в имени правителя.

Куда важнее то, что резчик штемпеля аверса не был должным образом подготовлен к своей профессиональной деятельности. Об этом свидетельствует неоправданно низкий рельеф как бы процарапанных, но в то же время оплывших букв легенды. Вместе с тем линии дифферента Ч, размещенного правее изображения боспорского государя, прорезаны весьма аккуратно и ограничены точками (рис. 1,1$)$. Столь же твердой рукой выполнен и портрет боспорского государя.

Вполне возможно, что над чеканом лицевой стороны этой монеты работало два мастера. Допускаем, что последний из них вырезал и штемпель для реверса. Судим по четкости линий букв и по сравнительно высокохудожественно исполненному, по боспорским меркам, конечно, бюсту императора.

Мы находим последнее обстоятельство весьма существенным. Ведь оно, как нам кажется, достаточно убедительно говорит о том, что монеты выпускала группа монетчиков, в разной степени подготовленных к выполнению поставленных им задач. Но вряд ли они могли трудиться в мастерской фальшивомонетчика. Ведь подобное разделение труда вряд ли имело смысл в условиях подпольного производства. Заключаем, что эти два мастера работали на государственном монетном дворе.

Попытаемся обосновать наше допущение. Ведь пока нам удалось изучить только одну монету этой разновидности. Но на данный момент их известно уже шесть экземпляров ${ }^{17}$. И, что крайне интересно, лицевые стороны этих монет были оформлены с помощью чекана, использовавшегося для эмиссии статеров 618 г. б. э. ${ }^{18}$ (321/322 г. н. э.) ${ }^{19}$

«Rhadamsades» немыслимые «Farsanz», «Ininfimey», «Teyran» и «Radamsad». А фразу «Тиберии Юлии» он перевел не как «Tiberian-Julian dynasty», а как «Tiberii Yulii» [Панченко, 2020, с. 99]. Полагаем, что имеем дело с очередным студенческим «конспектом» В.В. Панченко [Панченко, 2017, с. 52], обильно разбавленным его нелепыми домыслами. Остается только посетовать крымским издателям, вынужденным публиковать, по-видимому, без какой бы то ни было проверки труды такого автора.

${ }^{16}$ Так, собственно, и полагают администраторы сайта «Монеты Боспора». См.: Монета 770-5138. URL: https://bosporan-kingdom.com/770-5138/ (дата обращения: 04.07.2020).

${ }^{17}$ Паспорт монеты: 770-5138-1. URL: https://bosporan-kingdom.com/770-5138/1.html (дата обращения: 04.07.2020); Паспорт монеты: 770-5138-3. URL: https://bosporan-kingdom.com/770-5138/3.html (дата обращения: 04.07.2020); Паспорт монеты: 770-5138-4. URL: https://bosporan-kingdom.com/770-5138/4.html (дата обращения: 04.07.2020); Паспорт монеты: 770-5138-2. URL: https://bosporan-kingdom.com/7705138/2.html (дата обращения: 04.07.2020); Паспорт монеты: 770-5138-6. URL: https://bosporankingdom.com/770-5138/6.html (дата обращения: 04.07.2020).

${ }^{18}$ Изображение и описание этой монеты приведено на сайте «Монеты Боспора» См.: Паспорт монеты: 7675153-1. URL: https://bosporan-kingdom.com/767-5153/1.html (дата обращения: 04.07.2020). Его же администраторы обратили внимание на сходство изображений боспорского государя на аверсе монет на рис. $1,1,7$.

19 Это обстоятельство было подмечено администраторами сайта «Монеты Боспора». Однако они пришли к выводу, что эта монета также является репликой. К сожалению, они не сочли нужным обосновать это заключение. Мы же, в свою очередь, полагаем, что эта монета - официального чекана. Ведь она 
(рис. 1, 7). Однако его немного модифицировали. Так, продольная гаста дифферента Ч изначально была довольно длинной, так что ее края выступали за правую и левую поперечные составляющие (рис. 1, 7). Но на изученной нами монете эти элементы соразмерны, а места их соприкосновения обозначены точками (рис. 1, 1). Столь же примечательны и буквы легенды. Если на статере 618 г. б. э. они четкие, хорошо читаемые, то на изучаемой нами монете, как уже было сказано выше, они оплывшие и как бы процарапанные. Полагаем, что ранее использовавшийся штемпель был значительно изношен. И монетчики в 631 г. б. э. были вынуждены его подправить. Так что у нас есть все основания полагать, что эмиссионный центр, использовавший дифферент $\Psi$, работал непрерывно с 618 до 631 г. б. э. Ведь в ином случае штемпель аверса вряд ли бы сохранился.

Заметим, что форма буквы «V» на реверсе статеров на рис. 1, 1, 2 практически безукоризненна. Да, на монете на рис. 1, 5 ее левая и правая гасты не сочленены должным образом. Первая составляющая не пересекается со второй в нижней точке буквы. Но достаточно ли этого для того, чтобы видеть в этом символе именно «К»? Полагаем, что нет. Похоже, что мы имеем дело с очевидной и, скажем, вполне допустимой небрежностью резчика. В любом случае он не вырезал на штемпеле вертикальную линию. Следовательно, перед ним не ставили задачу разместить именно «К». Да и не ясно, что могло побудить резчика штемпеля развернуть эту букву на $90^{\circ}$. Приходим к выводу, что на оборотной стороне изучаемой нами монеты была отчеканена именно «V». Следовательно, ее выпустили в 631 г. б. э., т. е. в конце периода правления Рескупорида V. Это, заметим, не противоречит предлагаемому нами прочтению легенды аверса и трактовке изображений на лицевой и оборотной сторонах.

Но вернемся к ранее не изученным монетам (рис. 1, 2-6). Для начала опишем их.

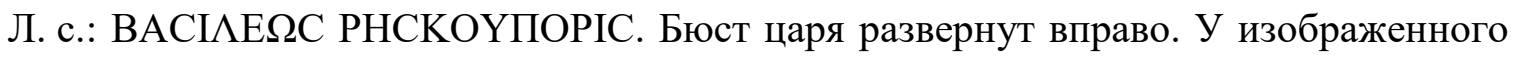
длинные волосы, их пряди переданы как параллельные кривые линии. Нижнюю и среднюю соединяет короткий штрих. Правее его подбородка и шеи размещен дифферент $\Psi$. Его формы не идеальны. Судя по оттиску, левая поперечная линия к моменту чеканки монеты была разрушена и прорезана заново. Эту работу выполнил неподготовленный мастер. Он разместил на штампе не прямую, а кривую линию.

O. с.: AVX. Первая буква с косой соединяющей линией. Левая гаста «V» сдвинута вверх и вправо. Так что она не соприкасается с правой составляющей этой буквы в нижней ее точке. Бюст мужчины в лавровом венке, развернутый вправо. Композиция вписана в окружность из крупных редких точек.

По-видимому, монета отчеканена из меди или бронзы. Судим по патине. К сожалению, на сайте «Монета Боспора» не указано, из какого металла или сплава она была изготовлена.

Монета в целом хорошей сохранности. Но на ее аверсе заметно повреждение, нанесенное острым твердым предметом. Возможно, что монету пытались сверлить. Диаметр ее неизвестен. Вес - 3,90 г. (рис. 1, 2).

Л. с.: То же.

О. с.: То же.

выполнена в том же стиле, что и подлинные монеты Рескупорида V [Анохин, 2011, № 2154-2203; Фролова, 1997b, с. 323-372, табл. LXXXVI, 20-23, LXXXVII-CXII]. Другое дело, что буквы легенды ее аверса выполнены в высоком рельефе. Полагаем, что монета была отчеканена вновь созданными штемпелями. А эмиссия 631 г. б. э. (334/335 г. н. э.) прошла с использованием изношенного и непрофессионально подрезанного штемпеля, на котором была к тому времени сильно изношена та часть поверхности, на которой была размещена легенда. Это, в свою очередь, также свидетельствует в пользу нашего допущения, что эмиссия изучаемых статеров прошла на государственных монетных дворах. В ином случае штемпели вряд ли бы так долго хранили, не используя для нужд производства. 
Монета очень плохой сохранности. Так что трудно судить о том, что за штемпеля были использованы при ее изготовлении. Заметно только, что «V» на ее реверсе оформлена так же, как и на статере на рис. 1, 2.

Монета плохой сохранности. Материал, диаметр и ее вес неизвестны (рис. 1, 3).

Л. с.: То же. Надпись не читаема.

O. с.: То же. Судя по особенностям начертания «V», ее оборотную сторону оформили тем же чеканом, который использовался при изготовлении статеров на рис. 1, 2, 3.

Монета плохой сохранности. Материал, диаметр и ее вес неизвестны (рис. 1, 4).

Л. с.: ВАСІАЕ...ОҮПОРІС. Бюст царя развернут вправо. Пряди волос наложены внахлест. Во всем остальном изображения и легенда схожи с размещенными на лицевой стороне статера на рис. 1,1 .

О. с.: То же. Полагаем, что ее оттиснули чеканом, задействованным при производстве статеров на рис. 1, 3, 4. Судим по форме «V».

Монета хорошей сохранности. Материал, диаметр и ее вес неизвестны (рис. 1, 5).

Л. с.: Надпись нечитаемая. Бюст царя вправо. У него короткие волосы.

О. с.: Различимы «V» и «A». Бюст императора вправо.

Монета плохой сохранности. Материал, диаметр и ее вес неизвестны (рис. 1, б).

Наше внимание к мелким деталям оформления отнюдь не случайно. Выявив их, мы можем выяснить, сколько пар штемпелей было задействовано для их производства. Осталось только выяснить, в каком порядке их использовали. Для этого изучим статер 618 г. б. э.

Л.c.: ВАСІ $\Lambda$ $\Omega$ РНСКОҮПОРІС. Буквы размещены неаккуратно, но они переданы четкими линиями. Бюст царя развернут вправо. У изображенного длинные волосы, их пряди переданы как параллельные кривые линии. Нижнюю и среднюю соединяет короткий штрих. Правее его подбородка и шеи размещен дифферент Ч. Его продольная составляющая длиннее, чем нужно, и выступает за левую и правую гасты. Места соединения линий выделены точками.

О.с.: HIX. Бюст мужчины в лавровом венке, развернутый вправо. Композиция вписана в окружность из крупных редких точек.

По-видимому, монета отчеканена из меди или бронзы. Судим по цвету окиси. К сожалению, на сайте «Монета Боспора» не указано, из какого металла или сплава она была изготовлена.

Монета хорошей сохранности. Диаметр и вес монеты неизвестны (рис. 1, 7).

Учитывая вновь выявленные обстоятельства, полагаем, что первой была отчеканена монета на рис. 1, 2. Судим по тому, что при ее производстве был использован слегка доработанный штемпель, который оставил оттиск на аверсе монеты 618 г. б. э. (рис. 1, 7). Причем, интересно, что в процессе использования он был разрушен. Судим по повреждению дифферента $\Psi$ (рис. 1, 2). Что же касается чекана реверса, то он был изготовлен заново. Обозначим использованные при производстве этого статера штемпели как Obv1 и Rev1.

Полагаем, что позже был изготовлен чекан лицевой стороны, оставивший свой след на статере на рис. 1, 1. Его сформовали с помощью патрицы, т. е. по той же технологии, что была использована в процессе чеканки статеров Фофорса (285/286-309/310) [Чореф, 2014, с. 323-365]. Причем штемпель лицевой стороны был в очередной раз доработан. Судим по тому, что у боспорского государя иная прическа - пряди переданы непересекающимися линиями. Для этой монеты был создан и новый штамп реверса. Он характерен 
тем, что правая и левая гасты «V» сходятся в ее нижней точке (рис. 1, 1). Обозначим используемые в процессе ее производства штемпели как Obv1a и Rev1a.

Трудно сказать, что за чеканы оставили оттиски на монетах на рис. 1,3 , 4. Ведь они сильно пострадали от времени. Однако заметно, что длинные нижняя и средняя пряди волос боспорского государя соединены короткой черточкой. $\mathrm{A}$ «V» на их реверсе похожа на символ на монете на рис. 1, 2. Допускаем, что при производстве этих монет использовали чеканы Obv1 и Rev1.

Куда лучше сохранился статер, фотография которого приведена на рис. 1, 5. Видно, что пряди волос боспорского государя на его аверсе спутаны. В то же время размещенный на нем дифферент весьма похож на такой же знак на лицевой стороне монеты на рис. 1, 2. Не менее интересен и реверс этой монеты. Он во всем похож на оборотную сторону статера на рис. 1, 2, только точки «V» значительно крупнее. Заключаем, что статер на рис. 1, 5 был отчеканен доработанными чеканами, использовавшимися при производстве монеты на рис. 1, 2. Обозначаем их как Obv1b и Rev1b.

Что же касается статера на рис. 1, 6, то он сохранился довольно плохо. Однако заметно, что у боспорского государя на аверсе короткие волосы. А на реверсе «V» столь же пропорциональна, что и на рис. 1,1 . Заключаем, что эту монету отчеканили штемпелями Obv2 и Rev1a.

Итак, у нас есть все основания полагать, что в процессе производства статеров 631 г. б. э. использовали четыре штемпеля аверса и три реверса.

Очевидно, что столь педантичное отношение к элементам монетного оформления не могло быть характерно для фальшивомонетчиков. Есть все основания полагать, что мастера, участвовавшие в производстве изучаемых нами монет, выполняли заказ, повидимому, правительственный.

Но при этом, похоже, мастера допускали ошибки. С этой точки зрения довольно интересным фактом является появление бюста мужчины с короткими волосами на аверсе монеты на рис. 1, 6. Дело в том, что Рескупорида V, как правило, изображали длинноволосым [Анохин, 2011, № 2154-2203; Фролова, 1997b, с. 323-372, табл. LXXXVI, 20-23, LXXXVII-CXII]. Трудно судить по столь плохо сохранившейся монете, но все же считаем возможным допустить, что мастера по ошибке разместили на лицевой стороне монеты изображение правящего императора. Дело в том, что на монетах Боспора римского периода всегда изображали римских государей с короткими прическами. Заметим, что такого рода ошибки говорят о довольно низком уровне подготовки резчиков штемпелей, работавших в 631 г. б. э. на монетном дворе, пользовавшимся дифферентом 4.

Итак, что же мы получили? Доступные для изучения монеты были отчеканены в 631 г. б. э. на провинциальном монетном дворе, использовавшем дифферент Ч. При этом были использованы связанные штемпели. Причем чеканы лицевой стороны были сформованы с помощью доработанного чекана, использовавшегося при выпуске статеров 618 г. б. э. тем же монетным двором. Похоже, что эмиссия была достаточно обильная. В результате последний из чеканов, созданный как разновидность штампа 618 г. б. э., был разрушен. Монетчики были вынуждены создать новый штемпель, оставивший свой оттиск на монете на рис. 1: 6.

Что же касается штампов реверса, то их прототип был изготовлен специально для организации эмиссии статеров 631 г. б. э. В дальнейшем его подрабатывали для продолжения выпуска монет этой серии. Есть все основания полагать, что он и его разновидности являются связывающими элементами, позволяющими воссоздать картину событий.

Выявленные обстоятельства как нельзя лучше и точнее свидетельствуют в пользу нашего тезиса. Об официальности эмиссии говорит не изящество оформления поздних боспорских монет - оно не наблюдалось, а технологичность процесса, свидетельствующая о стремлении к стандартизации, необходимой при массовом производстве платежных средств. 

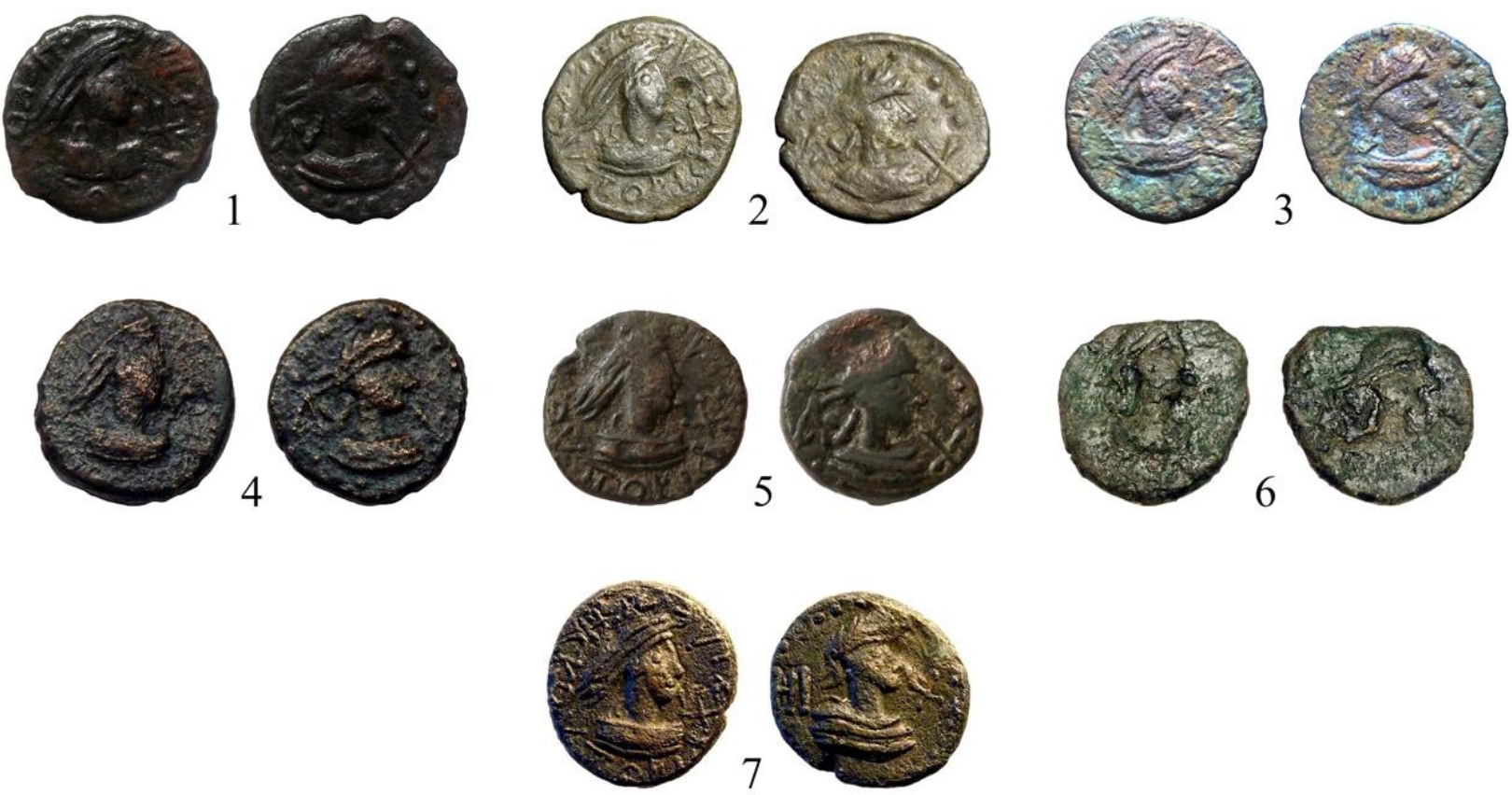

Рис. 1. Изучаемые статеры: 1-6-631 г. б. э.; 7 -618 г. б. э.

Fig. 1. Studied staters: $1-6-631$ Bosp. Era; $7-618$ Bosp. Era

\section{Список сокращений}

КБН - Корпус боспорских надписей. М., Л.

\section{Список литературы}

1. Абрамзон М.Г. 2011. Корпус боспорских кладов античных монет. Т. ІІ. Клады из новых поступлений в Керченский историко-культурный заповедник (2009-2010 гг.). Симферополь, Керчь, АДЕФ-Украина (Боспорские исследования. Suppl. 2), 280.

2. Абрамзон М.Г., Новичихин А.М., Сапрыкина И.А., Смекалова Т.Н. 2019. Третий ГайКодзорский клад позднебоспорских статеров. М., Институт археологии РАН, 344.

3. Абрамзон М.Г., Фролова Н.А. 2007-2008. Корпус боспорских кладов античных монет. Т. 1. 1834-2005 гг. Симферополь; Керчь, АДЕФ-Украина (Боспорские исследования. Suppl. 2), 872.

4. Абрамзон М.Г., Фролова Н.А., Горлов Ю.В. 2002. Клады античных монет на Юге России (по материалам Краснодарского края). М., Эдиториал УРСС, 592.

5. Андриевский Д.В., Чореф М.М. 2015. Вновь найденный боспорский статер 631 г. б. э. как исторический источник. В кн.: Коричко А.В. (отв. ред.). Актуальные проблемы фундаментальных и прикладных дисциплин и методик их преподавания: Материалы очно-заочного семинара (г. Нижневартовск, 26 декабря 2015 г.). Нижневартовск, НВГУ: 91-94.

6. Анохин В.А. 2011. Античные монеты Северного Причерноморья. Киев, Стилос, 328.

7. Молев Е.А. 2017. Боспорские древности. Проблемы политической, социальной и культурной истории античного Боспора. Нижний Новгород, ННГУ, 339.

8. Монета: 770-5138. URL: https://bosporan-kingdom.com/770-5138/ (дата обращения: 04.07.2020).

9. Панченко В.В. 2017. Морской поход племен Северного Причерноморья 266 г. н. э. на Гераклею и ситуация на Боспоре. Причерноморье. История, политика, культура. Вып. XXII (VII): 52-62.

10. Паспорт монеты: 767-5153-1. URL: https://bosporan-kingdom.com/767-5153/1.html (дата обращения: 04.07.2020).

11. Паспорт монеты: 770-5138-1. URL: https://bosporan-kingdom.com/770-5138/1.html (дата обращения: 04.07.2020).

12. Паспорт монеты: 770-5138-2. URL: https://bosporan-kingdom.com/770-5138/2.html (дата обращения: 04.07.2020).

13. Паспорт монеты: 770-5138-3. URL: https://bosporan-kingdom.com/770-5138/3.html (дата обращения: 04.07.2020). 
14. Паспорт монеты: 770-5138-4. URL: https://bosporan-kingdom.com/770-5138/4.html (дата обращения: 04.07.2020).

15. Паспорт монеты: 770-5138-6. URL: https://bosporan-kingdom.com/770-5138/6.html (дата обращения: 04.07.2020).

16. Соломоник Э.И. 1959. Сарматские знаки Северного Причерноморья. Киев, АН УССР. 180.

17. Струве В.В. (отв. ред.). Корпус боспорских надписей. М., Л., Наука. 951.

18. Фролова Н.А. 1997a. Монетное дело Боспора (середина I в. до н. э. - середина IV в. н. э.). Ч. І. Монетное дело Боспора 49/48 гг. до н. э. - 210/211 гг. н. э. М., Эдиториал УРСС, 448.

19. Фролова Н.А. 1997b. Монетное дело Боспора (середина I в. до н. э. - середина IV в. н. э.). Ч. II. Монетное дело Боспора 211-341/342 гг. н. э. М., Эдиториал УРСС, 536.

20. Чореф M.M 2012b. «Non multa, sed multum», или дифференты на монетах боспорского царства периода «скифских войн» как исторический источник. Stratum plus. № 4: 171-200.

21. Чореф М.М. 2011. Территориально-административное устройство Боспорского царства при Фарнаке II по нумизматическим данным. В кн.: Петербургский апокриф. Послание от Марка. Кишинев, Высшая антропологическая школа: 247-259.

22. Чореф M.M. 2012a. «Calamitas virtutis occasio», или к истории последних лет царствования Фарнака II. Via in tempore. История. Политология. Т. 22.7 (126): 44-59.

23. Чореф М.М. 2014а. Боспорское царство при Фофорсе: по данным нумизматики. Российский археологический ежегодник. 4: 323-365.

24. Чореф М.М. 2014b. К биографии Асандра: путь к престолу. Материалы по археологии и истории античного и средневекового Причерноморья. 6: 456-487.

25. Чореф М.М. 2015. Надчеканки на медных монетах боспорского архонта Асандра. Материалы по археологии и истории античного и средневекового Причерноморья. 7: 279-299.

26. Чореф М.М. 2017. Отзыв на статью В.В. Панченко «Морской поход племен Северного Причерноморья 266 г. н. э. на Гераклею и ситуация на Боспоре». В кн.: Солодкин Я.Г. (отв. ред.). Материалы и исследования по истории России. Вып. 2. Нижневартовск, НВГУ: 46-55.

27. Яценко С.А. 2001. Знаки-тамги ираноязычных народов древности и раннего средневековья. Москва, Восточная литература, 190.

28. Sestini D. 1831. Descrizione d'alcune medaglie greche del museo del signore barone Stanislao di Chaudoir. Firenze, Presso Guglielmo Piatti, 156.

\section{References}

1. Abramzon M.G. 2011. Korpus bosporskikh kladov antichnykh monet [Corpus of the Bosporus treasures of antique coins]. Vol. II. Klady iz novykh postupleniy v Kerchenskiy istoriko-kul'turnyy zapovednik (2009-2010 gg.) [Treasures from New Acquisitions to the Kerch's Historical and Cultural Reserve (2009-2010)]. Simferopol, Kerch, ADEF-Ukraina (Bosporos Studies. Suppl. 2), 280 (in Russian).

2. Abramzon M.G., Novichikhin A.M., Saprykina I.A., Smekalova T.N. 2019. Tretiy GayKodzorskiy klad pozdnebosporskikh staterov [The Third hoard of late Bosporan staters from Gai-Kodzor site]. M., Institut arkheologii RAN, 344 (in Russian).

3. Abramzon M.G., Frolova N.A. 2007-2008. Korpus bosporskikh kladov antichnykh monet [Corpus of the Bosporus treasures of antique coins]. Vol. 1. 1834-2005 gg. [1834-2005]. Simferopol; Kerch, ADEF-Ukraina (Bosporos Studies. Suppl. 2), 872 (in Russian).

4. Abramzon M.G., Frolova N.A., Gorlov Yu.V. 2002. Klady antichnykh monet na Yuge Rossii (po materialam Krasnodarskogo kraya) [Treasures of antique coins in the south of Russia (based on materials from the Krasnodar Territory)]. M., Editorial URSS, 592 (in Russian).

5. Andriyevskiy D.V., Choref M.M. 2015. Vnov' naydennyy bosporskiy stater 631 g. b. e. kak istoricheskiy istochnik [The Newly Found Bosporus Stater 631 of bosporan era as a historical source]. In: Korichko A.V. (ed.). Aktual'nyye problemy fundamental'nykh i prikladnykh distsiplin i metodik ikh prepodavaniya: Materialy ochno-zaochnogo seminara (g. Nizhnevartovsk, 26 dekabrya 2015 g.) [Actual problems of fundamental and applied disciplines and methods of teaching them: Materials of a part-time seminar (Nizhnevartovsk, December 26, 2015)]. Nizhnevartovsk, NVGU: 91-94 (in Russian).

6. Anokhin V.A. 2011. Antichnyye monety Severnogo Prichernomor'ya [Antique coins of the Northern Black Sea region]. Kiyev, Stilos, 328 (in Russian).

7. Molev Ye.A. 2017. Bosporskiye drevnosti. Problemy politicheskoy, sotsial'noy i kul'turnoy istorii antichnogo Bospora [Bosporus antiquities. Problems of the political, social and cultural history of ancient Bosporus]. Nizhniy Novgorod, NNGU, 339 (in Russian). 
8. Moneta: 770-5138. URL: https://bosporan-kingdom.com/770-5138/ (date of the application: 04.07.2020).

9. Panchenko V.V. 2017. Morskoy pokhod plemen Severnogo Prichernomor'ya 266 g. n. e. na Gerakleyu i situatsiya na Bospore [Sea voyage of the tribes of the Northern Black Sea region, 266 A. D. on Heraclea and the situation on the Bosporus]. In: Prichernomor'ye. Istoriya, politika, kul'tura [Black Sea Region. History, politics, culture]. Iss. XXII (VII): 52-62 (in Russian).

10. Pasport monety: 767-5153-1. URL: https://bosporan-kingdom.com/767-5153/1.html (date of the application: 04.07.2020).

11. Pasport monety: 770-5138-1. URL: https://bosporan-kingdom.com/770-5138/1.html (date of the application: 04.07.2020).

12. Pasport monety: 770-5138-2. URL: https://bosporan-kingdom.com/770-5138/2.html (date of the application: 04.07.2020).

13. Pasport monety: 770-5138-3. URL: https://bosporan-kingdom.com/770-5138/3.html (date of the application: 04.07.2020).

14. Pasport monety: 770-5138-4. URL: https://bosporan-kingdom.com/770-5138/4.html (date of the application: 04.07.2020).

15. Pasport monety: 770-5138-6. URL: https://bosporan-kingdom.com/770-5138/6.html (date of the application: 04.07.2020).

16. Solomonik E.I. 1959. Sarmatskiye znaki Severnogo Prichernomor'ya [Sarmatian signs of the Northern Black Sea region]. Kiyev, AN USSR. 180.

17. Struve V.V. (ed.). 1965. Korpus bosporskikh nadpisei [Corpus of Bosporan Inscriptions]. M., L, Nauka. 951 (in Russian).

18. Frolova N.A. 1997a. Monetnoye delo Bospora (seredina I v. do n. e. - seredina IV v. n. e.) [Bosporan Coinage (Middle of $1^{\text {st }}$ Century B. C. - Middle of $4^{\text {th }}$ Century A. D.)]. Pt. I. Monetnoye delo Bospora 49/48 gg. do n. e. $-210 / 211$ gg. n. e. [Bosporan Coinage in 49/48 B. C. $-210 / 211$ A. D.]. M., Editorial URSS, 448 (in Russian).

19. Frolova N.A. 1997b. Monetnoye delo Bospora (seredina I v. do n. e. - seredina IV v. n. e.) [Bosporan Coinage (Middle of $1^{\text {st }}$ Century B. C. - Middle of $4^{\text {th }}$ Century A. D.)]. Pt. II. Monetnoye delo Bospora 211-341/342 gg. n. e. [Bosporan Coinage in 211-341/342 A. D.]. M., Editorial URSS, 536 (in Russian).

20. Choref M.M. 2012b. «Non multa, sed multum», ili differenty na monetakh bosporskogo tsarstva perioda «skifskikh voyn» kak istoricheskiy istochnik [«Non multa, sed multum», or Differents on the Coins of the Bosporus Kingdom during the «Scythian Wars» as a Historical Source]. In: Stratum plus 4: 171-200 (in Russian).

21. Choref M.M. 2011. Territorial'no-administrativnoye ustroystvo Bosporskogo tsarstva pri Farnake II po numizmaticheskim dannym [Territorial-Administrative Structure of the Bosporus Kingdom under Pharnaces II, based on Numismatic Data]. In: Peterburgskiy apokrif. Poslaniye ot Marka [SaintPetersburg Apocrypha. Epistle of Mark]. Kishinev, Vysshaya antropologicheskaya shkola: 247-259 (in Russian).

22. Choref M.M. 2012a. «Calamitas virtutis occasio», ili k istorii poslednikh let tsarstvovaniya Farnaka II [«Calamitas virtutis occasion», or the history of the last years of the reign of Pharnaces II]. In: Via in tempore. Istoriya. Politologiya [Via in tempore. History. Political science]. Vol. 22. 7 (126): 44-59 (in Russian).

23. Choref M.M. 2014a. Bosporskoye tsarstvo pri Foforse: po dannym numizmatiki [Bosporan Kingdom under Theothorses (on the basis of numismatic data)]. In: Rossiyskiy arkheologicheskiy yezhegodnik [Russian Archaeological Yearbook]. 4: 323-365. 23 (in Russian).

24. Choref M.M. 2014b. K biografii Asandra: put' k prestolu [To the biography of Asander: the path to the throne]. In: Materialy po arkheologii i istorii antichnogo i srednevekovogo Prichernomor'ya [Proceedings in Archaeology and History of Ancient and Medieval Black Sea region]. 6: 456-487 (in Russian).

25. Choref M.M. 2015. Nadchekanki na mednykh monetakh bosporskogo arkhonta Asandra [Countermarks on copper coins of the Bosporus archon Asander]. In: Materialy po arkheologii i istorii antichnogo i srednevekovogo Prichernomor'ya [Proceedings in Archaeology and History of Ancient and Medieval Black Sea region]. 7: 279-299 (in Russian).

26. Choref M.M. 2017. Otzyv na stat'yu V.V. Panchenko «Morskoy pokhod plemen Severnogo Prichernomor'ya 266 g. n. e. na Gerakleyu i situatsiya na Bospore» [Feedback on the article by V.V. Panchenko «Sea voyage of the tribes of the Northern Black Sea Region, 266 A. D. on Heracles and 
the situation on the Bosporus»]. In: Solodkin Ya.G. (ed.). Materialy i issledovaniya po istorii Rossii [Materials and research on the history of Russia]. Iss. 2. Nizhnevartovsk, NVGU: 46-55 (in Russian).

27. Yatsenko S.A. 2001. Znaki-tamgi iranoyazychnykh narodov drevnosti i rannego srednevekov'ya [Signs - tamgas of the Iranian-speaking peoples of antiquity and the early Middle Ages]. M., Vostochnaya literature, 190 (in Russian).

28. Sestini D. 1831. Descrizione d'alcune medaglie greche del museo del signore barone Stanislao di Chaudoir. Firenze, Presso Guglielmo Piatti, 156.

\section{ИНФОРМАЦИЯ ОБ АВТОРЕ}

Чореф Михаил Михайлович, кандидат исторических наук, научный сотрудник Национального исследовательского Нижегородского государственного университета им. Н.И. Лобачевского, г. Нижний Новгород, Россия

\section{INFORMATION ABOUT THE AUTHOR}

Mikhail M. Choref, candidate of historical sciences, researcher at the National Research Nizhny Novgorod State University named after N.I. Lobachevsky, Nizhny Novgorod, Russia 